\title{
Business and Leisure "Bleisure" in Organization: Antecedents and Outcomes
}

\author{
Ardian Adhiatma ${ }^{\bowtie}$, Nailil Muna, Olivia Fachrunnisa \\ Faculty of Economics, Universitas Islam Sultan Agung, Semarang, Indonesia
}

\section{Info Article}

History Article:

Submitted 2 July 2019

Revised 2 November 2019

Accepted 2 January 2020

\section{Keywords:}

Bleisure (business and leisure);

Gamification; Creative Intel-

ligence; Innovation Performance.

\begin{abstract}
The purpose of this study is to explore the concept of bleisure (business and leisure) in an organization along with its antecedents and outcomes. Bleisure is a combination of completing work and entertainment or a pleasant situation at the same time. The sample used in this study were 106 respondents who work in Event Organizer (EO). Data collection methods in this study used questionnaires. Data was analyzed by using regression test. The results of this study indicate that if people work in an organization that combines business and leisure (bleisure), they will have the creativity and high innovation performance, and the application of business and leisure (bleisure) can be achieved through mobile working style and gamification. Bleisure or a combination of fun activities and work can enhance creative intelligence and innovation performance for individuals in completing work, every person will be more creative and innovative. Leisure and work are related things, when individuals are burdened with assignments, the application of leisure in an organization is one of the effective things.
\end{abstract}

\section{Business dan Leisure "Bleisure" dalam Organisasi: Anteseden dan Hasil}

\begin{abstract}
Abstrak
Tujuan dari penelitian ini adalah untuk mengeksplorasi konsep bleisure (business and leisure) dalam suatu organisasi bersama dengan anteseden dan hasil. Bleisure adalah kombinasi dari penyelesaian pekerjaan dan hiburan atau situasi yang menyenangkan dalam waktu yang sama. Sampel yang digunakan dalam penelitian ini adalah 106 responden yang bekerja di Event Organizer (EO). Metode pengumpulan data dalam penelitian ini menggunakan kuesioner. Data dianalisis dengan menggunakan uji regresi. Hasil penelitian ini menunjukkan bahwa jika seseorang bekerja dalam organisasi yang menggabungkan business and leisure (bleisure), mereka akan memiliki kreativitas dan kinerja inovasi yang tinggi, serta penerapan business and leisure (bleisure) dapat dicapai melalui gaya kerja mobile dan gamification. Bleisure atau kombinasi dari aktivitas yang menyenangkan dan pekerjaan dapat meningkatkan kreativitas dan inovasi, ketika individu merasakan kejenuhan dalam tugasnya, maka aplikasi yang menyenangkan dalam organisasi adalah satu cara yang efektif.
\end{abstract}

JEL Classification: M1, M10

How to Cite: Adhiatma, A., Muna, N., \& Fachrunnisa, O. (2019). Business and Leisure "Bleisure" in Organization: Antecedents and Outcomes. Jurnal Dinamika Manajemen, 10(2), 216-228.

${ }^{\square}$ Correspondence Address

Jl. Kaligawe Raya KM 4, Genuk, Semarang

Email: ardian@unissula.ac.id 


\section{INTRODUCTION}

Today has become an era of leisure economy where fun activities are transformed into activities that generate a plus point in the economic field. Some companies have applied leisure in their work such as Google and Facebook (Karl, 2005). Leisure economy comprises positive pleasures at work, such as social activities, public celebrations, humour, game entertainment and opportunities for individual development (Grant et al., 2014).

The quality of experience becomes the main matter for the leisure economy players, which includes several things such as education, entertainment, and aesthetics (Pine \& Gilmore, 2011). Some studies have found that young workers want more leisure in the workplace, in addition suggest that managers are suggested to realize the need to create a fun and creative work environment so that it can maintain a productive workforce (Karl, 2005).

The combination of business and leisure (bleisure) is now widely applied by individuals to complete their work. Blackshaw (2017) argued that job had become leisure, and leisure becomes a job. The characteristics of leisure can be seen from the freedom of time and space also more relaxed activities. Other research has found that leisure includes feelings of relaxation, excitement, and freedom (Kleiber et al., 2011). There are many people feel depressed with their work, so leisure is very necessary for completing a job. Leisure has function to reduce stress in work and daily life. So that leisure plays an important role in human life, especially when an individual has very difficult job. It is important for employees to have fun at work to be trusted by managers and service organizations. This is because managers are aware the importance of the relationship between employees who can enjoy leisure in completing their tasks and customers have a pleasant experience.

Leisure, creativity, and humor have a positive effect that can reduce employee absences, retain high quality people, and reduce turnover the employee. Thus, when there is a lack of leis- ure or pleasure at work, the level of work involvement of employees will be low and this will affect the goals of the organization. The Google company has implemented a bleisure application by combining fun at work through many ways. For example, the company celebrates April Fool's Day every year, giving employees the freedom to play volleyball and table tennis during breaks, and incorporating leisure into their office design. Google believes that if a company implements leisure in the workplace it will be able to be the primary means of promoting employee engagement and creativity. Hence, it can be concluded that leisure plays an important role in reducing stress and increasing positive energy for individuals. This is especially needed for workers who apply a mobile working style.

A mobile working style allows individuals to complete their work by moving from one workplace to another, so that it offers a high level of leisure in the form of freedom (Teodoro et al., 2014). This working style also allows the application of the concept of gamification in the workplace. Gamification or the use of game concepts in non-game contexts has influenced several things such as business, personal pleasure (leisure), and social life. Other studies have found that leisure activities can affect the creativity of workers (Dahlin et al., 2004; Jeppesen \& Lakhani, 2010). In addition, the benefits of leisure in work can also affect creativity and individual innovation performance (Medaille, 2010).

On the other hand, there are several studies found that time pressure as an indicator of gamification has a negative influence towards creativity. Because it makes individuals in a rush and unfocused in completing work triggered by game elements, have received attention because of their significant influence on employees' engagement, performance, and knowledge contribution. While recent research has explored the significance of game elements, there has been insufficient focus on the relations among game dynamics, user experience, and creative ideation. Subsequently, this research aims to investigate the effect of game dynamics on creative ideation. Inspired by the broaden-and-build theory and other research 
on cognitive processes, this study introduced two parallel mediators: transcendent and intellectual experiences. To test the research model, 508 samples were administered to employees of an IT organisation that has incorporated gamification along with enterprise social network. The results demonstrated partial mediation between the game dynamics (collaboration and network exposure. So that the combination of business and leisure (bleisure) is expected to be combat mediator for gamification and creative intelligence. Research on business and leisure is examined separately, but in this study business and leisure became element that can be used to improve creative intelligence and innovation performance.

The novelty of this research was the combination of business and leisure (bleisure) can used to mediate gamification and creative intelligence and also to improve the employee's innovation performance in organization. However, to the best of our knowledge, there have not been many studies that examine the concepts of business and leisure with their antecedents and effects. Thus, this study will examine the antecedents and effects of bleisure.

\section{Hypothesis Development \\ Relationship between Mobile Working Style and Bleisure}

Mobile working is an option that allow worker to be accomplish the work outside of the traditional boundaries in standard organization of work in terms of different dimensions such as amount, distribution of working time and working place (Spreitzer et al, 2017). Mobile work usually include flexible working hours,part-time work, job sharing, shift, weekend work,overtime, annual hours, flexi time, temporary work, flexible leave arrangements, and working not in office (Berkery et al, 2017). Mobile working is the completion of work that crosses locational boundaries and uses technology in a work (Martins et al., 2004). Mobility is the ability of individuals to move freely in a certain time and space when interacting with their mobile devices (Hislop \& Axtell, 2007). Mobility among individuals is different, depends on the location of work and the division of time for organizations or offices, homes and other places. According to Mobile workers are people who work in different locations and travel far from the office using technology to complete their tasks (Axtell et al., 2008). In addition, mobile workers also involve communication with several other people in the same time to complete their work (Siha \& Monroe, 2006).

Individuals who work by moving from one workplace to another or what so called as mobile workers sometimes have work pressure in completing their tasks. It will interfere with individual performance, therefore Bleisure or a combination of completing tasks with leisure can be applied in a work to reduce the work pressure faced by individuals. Business is the ability of organizations to use resources in order to provide services or products to users (Laguna \& Marklund, 2005). While leisure is fun and relaxe activity can be done outside of work (Beaton \& Funk, 2008). Leisure is free time available while working, where this leisure time can be used with fun activities determined by the individual (Baud-Bovy \& Lawson, 2002). Freedom becomes the main key to leisure (Pigram \& Jenkins 2006) and can be used to individual desires (Broadhurst, 2008). Bleisure is a combination of the completion of work and entertainment or a pleasant atmosphere at the same time.

Mobile workers or people who work by shifting assignments feel free because they can apply leisure in their jobs and feel more efficient in completing their work (Chevron \& Primeau (1996). Mobile working that is applied by an organization is useful to reduce the stress of individuals because at work they are not burdened with time of work that has been determined as organizations in general. Besides that, the benefits of mobile working is that people feel more flexible and have freedom when working and finishing tasks, so individual can applied leisure in work (Watson \& Lightfoot, 2003).

Work that uses hourly technology as applied in mobile work does not make individuals feel depressed, that means individuals feel comfortable and happy at work even though in 
completing the work (Jackson et al., 2009). Flexible work can reduce the workload of individuals because the work system provides freedom and independence in the workplace for individuals. From an individual perspective, flexible work systems increase autonomy in work arrangements (Tremblay, 2002). Freedom can produce positive social effects (Alstott, 1999). This freedom can be obtained by individuals when doing job mobility in completing their tasks. A mobile working may provide opportunities for employers. previous study investigates the longterm effects of mobile working on workers with regard to job satisfaction and leisure time (Uglanova \& Dettmers, 2018).

Greater flexibility in working conditions as implemented in mobile working also gives employees more freedom in the non-work domain, and therefore, with more opportunities to pursue pleasure. Flexitime, for example, allows employees to start their work day early to participate in recreational activities in the afternoon. When taking long leave, most employees can set their own goals (Carr \& Tang, 2005). Based on the results of previous studies, if the opportunity to work on a mobile basis is applied in the organization, it will improve bleisure.

H1: Mobile working style has a positive effect on Bleisure.

\section{Relationship between Gamification and Bleisure}

Gamification refers to a process of improving services by implementing a game design in a non-game context to create values and experiences for individuals (Deterding \& Dixon, 2011; Huotari, 2012). Gamification is the use of characteristics of game pattern in a non-game context (Deterding et al, 2011). Gamification reflects the use of game pattern including the mechanism of progress (point system), player control, reward, problem-solving, and competition in non-game situation (Deterding et al., 2011; Kapp, 2012). Gamification is the application of game pattern in finishing work pleasantly and fastly and process of creating work activities as like playing games. Research found that gamification and game-based learning are different from entertainment-oriented games. Gamification is fun, it is designed not only for entertainment but also for completing work (Davidson, 2008; Hamari \& Koivisto, 2015). Game is always related to freedom. but games also have their own rules, creating learning environments in daily life that might distinguish from leisure and work situations. The concept of gamification has been explained that gamification and observation measurement is based on reorganization of work and leisure (McGonigal, 2011; Zichermann \& Cunningham, 2011; Kapp, 2012).

Gamification connects the structural game to productive results. Work can be made like playing so that with pleasure it will make individuals more productive and the free time can be used by turning leisure into an activity in the form of pleasant work. For example, Amazon customer reviews, the percentage of LinkedIn's personal profiles, and Yahoo! Answer point system are as a proof of 'gamified interfaces.

Work should be made like a game in order to make a productive job (McGonigal, 2011). The emphasis is on leisure time because it will expand both the time and the way that individuals become more productive. Gamification or the use of game elements in nongame context such as in the workplace can increase pleasure in work, work experience, and individual involvement (Deterding et al., 2011; Lee \& Hammer, 2011; Muntean, 2011). New employees, especially the $\mathrm{Y}$ generation, may find a gamified workplace more attractive because they value work experiences that are supportive, fun, engaging and rewarding, so if they work in the workplace which applied gamification they also feel the leisure when they are working (Bosworth, 2012). However, when employees use gamification they create challenge and fun at work, channeling attention to the task at hand. In accordance such as seeking challenges at work, have been shown to combat boredom effectively, it is because they can apply leisure while completing their task (Harju et al., 2014). 
Gamification can be differentiated from simple contests because gamification seeks to use elements from designed games (such as video games, board games, and sports) to enhance the fun or effectiveness of a game in a work environment. A game is designed when it is purposefully created with reinforcing contexts, interactions, and mechanisms that create a more immersive feeling of play. For example, fun atmosphere in the workplace because of gamification can improve the leisure of the employee (Mollick \& Rothbard, 2014). So, if an individual gets a gamification design work, it will increase the possibility of bleisure.

$\mathrm{H} 2$ : Gamification has positive effect on bleisure.

\section{Relationship between Bleisure and Creative Intelligence}

Creativity is the development of an idea that is new, original, useful, and has practical value and it is also in accordance with the organization conditions (Gino \& Ariely, 2012). Creativity as the ability of a person to develop an idea and find new ways to create opportunities that has benefit for the organization (Zimmerer \& Scarborough, 2008). Creativity in business activities can be used to find a business opportunity and create innovation, new ideas, new designs, new concepts, update old ideas into unique ideas, and have unusual ways of completing tasks (Akinboye, 2002).

Intelligence can be defined by several meanings, but most have similar definitions. Intelligence is the ability to solve problems within the organization, and to adapt and learn new things from experience (Santrock, 2007). Work which combine with leisure is found in the creative industries (Ravenscroft \& Gilchrist, 2009). They have interviewed people who work in creative industry, such as artists and graphic designers at different career stages and they found that the creative industry has strong allure, self-expression and pleasure and the absence of barriers between work and leisure because they are a source of satisfaction from individuals.
Leisure is an activity where individuals can use to rest, have fun, or even other productive activities such as developing their knowledge, working, or creating other creative ideas (Dumazedier, 2001). While other studies found that leisure time can affect creativity (Madjar et al., 2002; Dahlin et al., 2004; Jeppesen \& Lakhani, 2010) Hobbies or leisure can support creativity in the workplace through two things. First, individual leaders can use the skills developed when working on a hobby to solve problems within the workplace (Kotro, 2007). Second, individuals indirectly benefit from hobbies because leisure is proven to provide an important role in developing one's cognitive skills (Manoux et al., 2003). Leisure is not only for personal gain but also can improve the creative experience (Florida, 2012).

The boundary between leisure and work is no longer exists because both of them have blended with each other. A combination of work with pleasure or bleisure would increase the level of enthusiasm, job satisfaction, and individual creativity, communication and sense of cohesiveness in the organization (Ford et al., 2004). In addition, a pleasant workplace situation will strengthen an organizational culture in which the values, norms, and beliefs of the organization are strongly held by individuals. Pleasure when working is very desirable for individuals (Tews et al., 2012).

The existence of pleasure when working has an impact on the organization and the individual itself. With the pleasure, it affects individual job satisfaction, individual creativity, work commitment, behavior in the organization, and individual energy at work. Fun in work can reduce the level of individual absence, anxiety, and individual emotional fatigue. Most organizational leaders are convinced that a fun work environment increases creativity and promotes group cohesiveness (Ford et al., 2004; Pryor et al., 2010). Leisure in their workplace had a positive effect on employee creativity and innovation, work performance, and organizational commitment. Thus, if bleisure is created within 
an organization, it will increase the creative intelligence of the individual.

H3: Bleisure has positive effect on Creative Intelligence.

\section{Relationship between Bleisure and Innovati- on Performance}

Innovation is a process of creating new concepts and new ideas as a result of individual creativity (West et al., 2004; Serrat, 2009). Innovation is the development of an idea with a new service that produces national economic development and an increase in innovative employment. Innovation performance is the number of innovations that have been produced by individuals in an organization in terms of creating and developing an idea for organizational progress (Goffin \& Mitchell, 2005).

Previous research found that leisure is like a hobby plays an important role in the discovery of one's ideas and innovations (Dahlin et al., 2004). Leisure in the form of hobbies has contributed to the progress of creating new innovations (Lakhani \& Wolf, 2005). Research conducted by De Jong et al. (2010) found in a survey in the United Kingdom, that 6.2\% (2.9 million individuals) of consumer product users were responsible for the innovation of the household sector which involved the development and modification of these products. The discovery found that product innovation is made by people who combine working time with leisure. In fact, a job is said to be ideal when it is combined with leisure to increase comfort and satisfaction for individuals. Even now some organizations see the benefits of leisure to increase innovation and creativity of individuals in the workplace (Arora, 2011).

For example, Google provides pleasure in workplace and combines business with pleasure so that individuals can relax at work. Some of the facilities provided by Google's office include a haircut, swimming pool, game table, video game, and free food. Working on Facebook drives individual innovation. Social media companies like Facebook must treat individuals with an emphasis on a high-quality work environ- ment. Some of the benefits gained by individual in Facebook when working is free to ride anywhere, there are free computer accessories and free food vending machines.

Workplace fun, which is they combined leisure in their workplace had a positive effect on employee creativity and innovation, work performance, and organizational commitment (Pryor et al., 2010). Workplace fun was defined as follows, a fun work environment intentionally encourages, initiates, and supports a variety of enjoyable and pleasurable activities that positively impact the attitude and productivity of individuals and groups including their innovation performance. Therefore, if bleisure is applied in an organization, it will improve the innovation performance of individuals.

H4: Bleisure has positive effect on Innovation Performance

The research model is shown in Figure 1.

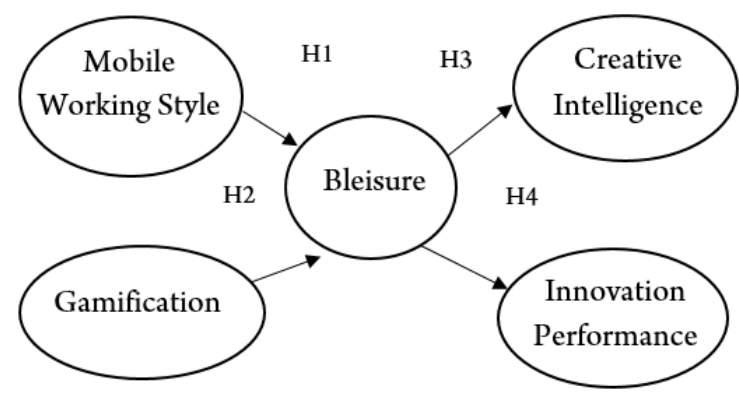

Figure 1. Empirical Model

\section{METHOD}

\section{Respondents}

The research object used in this study were people who work in Event Organizer (EO). The event organizer or EO is a business in the field of services whose task is to organize the entire series of events, from planning, preparation, and implementation to evaluation so that the whole series of events are carried out in accordance with the consumers desires. This work demands very high creativity and innovation. Data were collected through questionnaires distributed to 117 prospective respondents, but the returned 
questionnaires and the eligible samples used for this study were 106 respondents (response rate is $90.6 \%)$. The process of collecting data by giving questionnaires directly to the selected event organizer, and then filled out by its employees. There are two forms of questionnaire, paper and Google form. This study used a non-probability sampling, namely sampling where the chances of each respondent to be chosen are not the same or unknown (Rahi, 2017). The non-probability sampling technique used is judgmental sampling (purposive sample), which is a sample where the researcher used the assessment of certain criteria in the study. The criteria used are the length of work at least two years, experience in shifting assignments, and work in creative industry.

\section{Measurement}

\section{Mobile Working Style}

Mobile working style is defined as a form of work that moves to a location or place and uses technology to complete the work. Indicators used to measure mobile working style (Kakihara, 2004). The ability to move and use technology, to provide intense and smooth interaction between various people in order to complete work, and the ability is not to depend on a particular location. Items are ranked from 1 for strongly disagree to 5 for strongly agree.

\section{Gamification}

Gamification is defined as an individual motivation to complete work with game pattern. Indicators that can be used to measure gamification according to (Palmer et al., 2012; Blohm \& Leimester, 2013) are progress path, feedback and reward, social connections, group tasks, time pressure, and challenges. Items are ranked from 1 for strongly disagree to 5 for strongly agree.

\section{Bleisure}

Bleisure is defined as a combination of the completion of work and entertainment or a pleasant situation at the same time. Indicators that can be used to measure bleisure according to (Kleiber et al., 2011) are fun activities while working, time working as a hobby and comfort in work. Items are ranked from 1 for strongly disagree to 5 for strongly agree.

\section{Creative Intelligence}

Creative intelligence is defined as the ability to think and act creatively in completing work. Indicators for measuring creative intelligence which is adapted from Torrance (2000) are the ability to provide solutions, the ability to develop ideas, the ability to learn, the ability to use and obtain knowledge, the ability to adjust environmental demands. Items are ranked from 1 for strongly disagree to 5 for strongly agree.

\section{Innovation Performance}

Innovation performance is defined as the result of individual efforts in creating new ideas and concepts to achieve goals. Indicators for measuring innovation performance (Grewal, 2000; Janssen, 2000; Humphreys et al., 2005) are the ability to create new innovations, the ability to implement innovation and commitment to innovative activities. Items are ranked from 1 for strongly disagree to 5 for strongly agree.

\section{RESULT AND DISCUSSION}

The respondents consist of 63 men and 43 women, two respondents who have junior high school education level, 45 of senior high school level, 9 of associate degree level, 49 of undergraduate level, and 1 of postgraduate education level, aged 20-24 years as many as 20 people, 2530 years as many as 68 people, and over 30 years old as many as 18 people, and those who served as owners were 12 people, managers as many as 7 people, crew as many as 82 people, and project officers as many as 5 people.

\section{Statistical Analysis and Hypothesis Testing}

Multiple regression analysis was measured using t-test and significance of the proposed hypothesis. If $\mathrm{t}$-count is more than $\mathrm{t}$-table and significance is less than 0.05 then Hypothesis proposed is accepted, meaning that the independent variable has an effect on the dependent variable, and vice versa 
Table 1. Validity Test

\begin{tabular}{lllll}
\hline Variable & Indicator & Pearson Correlation & R-Table & Conclusion \\
\hline Mobile Working Style & MWS1 & .688 & .1909 & Valid \\
& MWS2 & .673 & & \\
& MWS3 & .666 & & \\
& MWS4 & .675 & & \\
& MWS5 & .685 & .1909 & Valid \\
\hline Gamification & G1 & .535 & & \\
& G2 & .660 & & \\
& G3 & .656 & & \\
& G4 & .514 & & \\
& G5 & .739 & .1909 & \\
& G6 & .748 & & \\
\hline Bleisure & BL1 & .852 & & \\
& BL2 & .884 & .1909 & \\
& BL3 & .843 & & \\
\hline Creative Intelligence & CI1 & .745 & & \\
& CI2 & .807 & & \\
& CI3 & .811 & & \\
& CI4 & .718 & & \\
\hline CI5 & .769 & .1909 & \\
& IP1 & .870 & & \\
& IP2 & .932 & & \\
& IP3 & .830 & & \\
\hline
\end{tabular}

if $\mathrm{t}$-count is smaller than $\mathrm{t}$-table and significance is more than 0.05 then Hypotheses is rejected, meaning that independent variable has no effect on the dependent variable. Table 1 describes the validity test. Table 2 describes the reliability test, and Table 3 describes the hypothesis testing result.

Table 2. Reliability Test

\begin{tabular}{lll}
\hline Variable & $\begin{array}{l}\text { Cronbach } \\
\text { Alpha }\end{array}$ & Conclusion \\
\hline Mobile Working Style & $.703^{*}$ & Reliable \\
Gamification & $.724^{*}$ & Reliable \\
Bleisure & $.818^{*}$ & Reliable \\
Creative Intelligence & $.828^{*}$ & Reliable \\
Innovation Performance & $.851^{*}$ & Reliable \\
${ }^{*}$ cronbach alpha $>.70$ & &
\end{tabular}

Hypothesis 1 states that mobile working style has an effect on bleisure. Based on the re- sults in Table 2, it is obtained a significance value of $<0.05$, the $t$-count value is 3.944 ( $t$ count $>1.6599$ ), the coefficient value is 0.334 , and the F-count value is 28.120 (f-count $>2.46$ ). This proves that mobile working style statistically has a positive effect on bleisure.

The test results of hypothesis 1 show that mobile working style has a positive effect on bleisure. Individuals who are able to move, are able to use technology in completing their work, are able to provide intense interaction to various people, are able to complete work well, and not depend on certain locations when completing work will increase individuals activities while working so that individuals feel more pleasant, comfortable, and also feel like doing their hobby while working. Individuals who work in event organizers are able to move and work not only in one place, they are able to complete work using technology and are able to provide intense interaction to the 
Table 3. Summary of Hypothesis

\begin{tabular}{llllllll}
\hline $\begin{array}{l}\text { Hypoth- } \\
\text { esis }\end{array}$ & Dependent Variable & $\begin{array}{l}\text { Independent } \\
\text { Variable }\end{array}$ & $\begin{array}{l}\text { Con- } \\
\text { stant }\end{array}$ & T-Test & F-Test & Conclusion & $\mathbf{R}^{2}$ \\
\hline H1 & Bleisure & Mobile & .334 & $3.944^{* *}$ & $28.120^{* *}$ & Supported & .353 \\
& & Working Style & & & & & \\
H2 & Bleisure & Gamification & .142 & $2.278^{* *}$ & $28.120^{* *}$ & Supported & .353 \\
H3 & Creative Intelligence & Bleisure & .912 & $7.646^{* *}$ & $58.457^{* *}$ & Supported & .360 \\
H4 & Innovation Performance & Bleisure & .558 & $5.984^{* *}$ & $35.804^{* *}$ & Supported & .256 \\
\hline${ }^{* *}$ Significant $p$-value $<.05$ & & & & & &
\end{tabular}

team or client so that it will make individual work more comfortable and enjoyable because their work is not just sitting in their office.

This supports the results of the study (Watson \& Lightfoot, 2003) which states that mobile working implemented by an organization is useful to reduce the stress of individuals because at work, they are not burdened with predetermined hours of work such as organizations in general. Another benefit of mobile working is that individuals feel more flexible and have freedom when working and carrying out tasks so that individuals will feel comfortable in completing work.

Hypothesis 2 states that there is a positive effect between gamification and bleisure. Based on the research in the table above, it is obtained a significance value of $<0.05$, the value of $t$-count is 2.278 ( $\mathrm{t}$ count $>1.6599$ ), the coefficient value is 0.142 , and the F-count value is 28.120 (f-count $>2.46)$. This proves that gamification statistically has a positive effect on bleisure.

The magnitude of the effect of mobile working style and gamification on bleisure can be seen from the coefficient of determination $\left(\mathrm{R}^{2}\right)$. The results show $\mathrm{R}$ Square of 0.353 means that the dependent variable can be explained by an independent variable of $35.3 \%$. While the other $64.7 \%$ is affected by other factors not included in the variables examined in this study.

The test results of hypothesis 2 show that gamification has a positive effect on bleisure, because with the progress path or giving easy tasks and continuing to more difficult tasks, giving gifts to individuals in the form of material or non-material for the completed work, utili- zation of customer social networks, giving work completed in a team, the deadline in completing work and the challenges in completing work will increase the activity of the individual at work so that it is more fun, felt like doing a hobby, and individuals feel comfortable at work. The gradual assignment of tasks, rewards directly after completing work, completing assignments in teams, giving assignments that are challenging for event organizers will improve bleisure, because completing work will be more fun and interesting because the method consists of an example of the application of games at work. This supports previous research (Bosworth, 2012) which states that individuals, especially for Y generation, work designs that apply gamification are very attractive to them, because gamification design provides supportive work experience, provides rewards directly after completing work, and also pleasure in finishing the work.

Hypothesis 3 states that there is an effect between bleisure and creative intelligence. Based on the results of the research in the table above, it is obtained a significance value of $<0.05$, the $t$-count value of 7.646 ( $t$-count $>$ $1.6599)$, the coefficient value of 0.912 and the calculated F-count value of 58.457 (f-count > 2.46). This proves that bleisure statistically has a positive effect on creative intelligence.

The magnitude of the effect of bleisure on creative intelligence can be seen from the coefficient of determination $\left(\mathrm{R}^{2}\right)$. The results show that $R$ Square is 0.600 which means that the dependent variable can be explained by an independent variable of $60 \%$. While the other $40 \%$ 
is affected by other factors not included in the variables examined in this study.

The results of testing hypothesis 3 show that bleisure has a positive effect on creative intelligence. Because fun activities when working, working time as a hobby, and feel comfort while working for individuals can increase the ability of individuals to provide solutions for organizations, the ability to develop ideas, improve individual abilities in learning, able to use and obtain knowledge and increase the ability of individuals in adjusting environmental demand. People who work in event organizers who feel happy in doing their jobs, they feel completing work as a hobby, and the convenience of doing tasks will make individuals more creative. Individuals will be able to find solutions, can develop new ideas for the progress of the organization and provide satisfaction for clients who use the event organizer services.

This result supported by Tews et al. (2012) which states that pleasure when working is highly desired and will have an effect on the organization and the individual itself. In addition, it also will increase individual job satisfaction, individual creativity, work commitment, behaviour in the organization, and individual energy while working. Fun at work can reduce the level of individual absence, anxiety, and individual emotional fatigue. Ajibua (2012) also found that leisure is a source of interest and satisfaction for individuals, so leisure provides opportunities for individuals' creativity and expression.

Hypothesis 4 states that bleisure has a positive effect on innovation performance. Based on the results of the research in the table above, it is obtained a significance value of $<0.05$, the $\mathrm{t}$-count value is 5.984 ( $\mathrm{t}$-count $>1.6599$ ), the coefficient value is 0.558 and the F-count value is 35.804 ( $\mathrm{f}$-count $>2.46$ ). This proves that bleisure has a positive effect on innovation performance.

The magnitude of the effect of bleisure on innovation performance can be seen as the coefficient of determination $\left(\mathrm{R}^{2}\right)$. The results show that the $\mathrm{R}$ Square value is 0.506 , which means that the dependent variable can be explained by an independent variable of 50.6\%. While the other $49.4 \%$ is affected by other factors not included in the variables examined in this study.

The test results of hypothesis 4 indicate that bleisure has a positive effect on innovation performance because fun activities when working for people who work in event organizers, feel like working as a hobby, and comfort while working can improve the ability of the event organizer in creating new innovations different from other event organizers, able to implement the new innovation, and increase commitment to innovative activities. This result supported by Arora (2011) job will be ideal when it is combined with leisure so that the comfort and satisfaction of individuals will increase. Even now, some organizations see the benefits of leisure to increase innovation and creativity of individuals in the workplace.

\section{CONCLUSION AND RECOMMENDATION}

Based on the results in this study, it is proved that the mobile work system and completing work with game thinking pattern (gamification) can improve bleisure on individuals because completing work will be more interesting. Mobile working carried out by individuals who work in event organizers makes them feel happier in completing work because their work is not monotonous sitting in the room. Besides that, gamification is done by event organizers such as giving rewards, teamwork, and challenges in completing tasks to become more interesting for individuals, so that it will improve the bleisure of the individual. Bleisure or a combination of fun activities and work can enhance creative intelligence and innovation performance for individuals in completing work, because of leisure, individuals will be more creative and innovative. Bleisure on the event organizer will make individuals more creative and innovative in determining the design, ideas, and concepts for the event organizer's client users.

Based on these findings, company managers must create business and leisure situations simultaneously. Individuals are the most im- 
portant assets in the organization, so individuals must work in a happy, comfortable and not feeling pressure because if an individual feels pressure when working, it will reduce individual performance.

Leisure and work are related things because elements of leisure can also be found when working. When individuals are burdened with assignments, the application of leisure in an organization is one of the effective things. A pleasant working situation like this is very desirable for young people because, with comfort and pleasure, it can explore the potential of the individual. So, if bleisure is applied by the leadership, individuals will be more creative and find new innovations in completing work and developing organizations.

Bleisure or a combination of business and leisure in completing work is new research that must be re-examined. Therefore, further researches can examine other variables outside of this study. In addition, other fields of industry can be studied which apply bleisure in completing their work.

The limitation of this study is that data collection for research only uses questionnaires, so the time is very limited. This caused not much interaction and explanation from the respondents. In addition, the selection of respondents in this study only on the event organizer company, so that the effect of the variables above is unknown in other industries. Future research is needed to examine this concept in other industries.

\section{REFERENCES}

Ajibua M, A. (2012) Involvement of Academic and NonAcademic Staff in Physical Leisure Activities in Tertiary Institutions in Ondo State. Unpublished Master Thesis. Department of Physical and Health Education, Obafemi Awolowo University, Ile-Ife, Osun State, Nigeria, 1-30.

Akinboye, J. O. (2002). Creativity and Innovation in Business. Nigerian Journal of Applied Psychology, 7(1), 1-41.

Alstott, A. L. (1999). Work vs Freedom: a Liberal
Challenge to Employment Subsidies a Liberal Challenge to Employment Subsidies. The Yale Law Journal, 108(5), 967-1058.

Arora, P. (2011). Online Social Sites as Virtual Parks: an Investigation into Leisure Online and Offline. The Information Society, 27(2), 113-120.

Axtell, C., Hislop, D., \& Whittaker, S. (2008). Mobile Technologies in Mobile Spaces: Findings from the Context of Train Travel. International Journal of Human-Computer Studies, 66(12), 902-915.

Baud-Bovy, M. (2002). Tourism and Recreation Handbook of Planning and Design. Oxford: Architectural Press.

Beaton, A. A., Funk, D. C., \& Funk, D. C. (2008). Leisure Sciences: an Interdisciplinary an Evaluation of Theoretical Frameworks for Studying Physically Active Leisure an Evaluation of Theoretical Frameworks for Studying Physically Active Leisure. Leisure Sciences: an Interdisciplinary Journal, 30(1), 37-41.

Berkery, E., Morley, M. J., Tiernan, S., Purtill, H., \& Parry, E. (2017). On the Uptake of Flexible Working Arrangements and the Association with Human Resource and Organizational Performance Outcomes. European Management Review, 14(2), 165-183.

Blackshaw, T (2017). Decentring Leisure: Rethinking Leisure Theory (Book Review). Annals of Leisure Research, 20(2), 240-242.

Blohm, I., \& Leimester, J. M. (2013). Gamification Design of IT-Based Enhancing Services for Motivational Support and Behavioral Change. Business and Information Systems Engineering, 5(4), 275-278.

Bosworth, A. (2012). Keas : Developing a Successful Game-Based Employee Wellness Program. Games for Health Journal, 1(3), 189-191.

Broadhurst, R. (2008). Managing environments for leisure and recreation. NY: Routledge

Carr, A. E., \& Tang, L.-P. (2005). Sabbaticals and Employee Motivation: Benefits, Concerns and Implications. Journal of Education for Business, 80(3),160-164.

Chevron, J., \& Primeau, M. (1996). The Telecommuting Innovation Opportunity. Journal of Consumer Marketing, 51(2), 74-80.

Dahlin, K., Taylor, M., \& Fichman, M. (2004). Today's Edisons or Weekend Hobbyists: Technical Merit and Success of Inventions by Independent Inventors. Research Policy, 33(8), 1167-1183. 
Ardian Adhiatma et al./ Business and Leisure "Bleisure" in Organization: Antecedents and Outcomes

Davidson, D. (2008). Beyond Fun: Serious Games and Media. Pittsburgh, PA: ETC Press.

De Jong, J., Von Hippel, E.A., Flowers, S. (2010). Comparing Business and Household Sector Innovation in Consumer Products: Findings from a Representative Study in the UK. Management Science, 58(9), 1669-1681.

Deterding, S., \& Dixon, D. (2011). From Game Design Elements to Gamefulness: Defining "Gamification." Proceedings. The 15th International Academic MindTrek Conference, 9-15.

Deterding, S., Khaled, R., Nacke, L. E., \& Dixon, D. (2011). Gamification: Toward a Definition. CHI 2011 GamifiCation Workshop. Proceedings, Vancouver, BC, Canada, 12-15.

Dumazedier, J. (2001). Lazer e Cultura Popular. São Paulo: Perspectiva.

Florida, R. (2012). The Rise of the Creative ClassRevisited: 10th anniversary edition. New York: Basic Books.

Ford, R. C., John W. Newstrom, and Frank S. McLaughlin. 2004. Making Workplace Fun More Functional. Industrial and Commercial Training, 36(3), 117-20.

Gino, F., \& Ariely, D. (2012). The Dark Side of Creativity: Original Thinkers Can be More Dishonest. Journal of Personality and Social Psychology, 102(3), 445-459.

Goffin, K., \& Mitchell, R. (2005). Innovation Management: Strategy and implementation using the pentathlon framework. 2nd Edition. NY: Palgrave MacMillan.

Grant, A. M., Berg, J. M., \& Cable, D. M. (2014). Job Titles as Identity Badges: How Self-Reflective Titles Can Reduce Emotional Exhaustion. Academy of Management Journal, 57(4), 1201-1225.

Grewal, R. (2000). The Role of the Social-Identity Function of Attitudes in Consumer Innovativeness and Opinion Leadership. Journal of Economic Psychology, 21(3), 233-252.

Hamari, J., \& Koivisto, J. (2015). International Journal of Information Management Why do People Use Gamification Services?. International Journal of Information Management, 35(4), 419-431.

Harju, L., Hakanen, J. J., \& Schaufeli, W. B. (2014). Job Boredom and its Correlates in 87 Finnish Organizations. Journal of Occupational and Environmental Medicine, 56(9), 911-918.

Hislop, D. And Axtell, C., (2007), To Infinity and
Beyond?: Workspace and the Multi-Location Worker. New Technology, Work and Employment, 24(1), 60-75.

Humphreys, P., Mcadam, R., \& Leckey, J. (2005). Longitudinal Evaluation of Innovation Implementation in SMEs. European Journal of Innovation Management, 8(3), 283-304.

Huotari, K. (2012). Defining Gamification a Service Marketing Perspective. Proceedings. The 16th International Academic MindTrek Conference, 17-22.

Jackson, P., Gharavi, H., Klobas, J., Jackson, P., \& Gharavi, H. (2009). Technologies of the Self : Virtual Work and the Inner Panopticon. Information Technology \& People, 15(3), 219243.

Janssen, O. (2000). Job Demands, Perceptions of Effort-Reward Fairness and Innovative Work Behaviour. Journal of Occupational and Organizational Psychology, 73(3), 287-302.

Jeppesen, L. B., \& Lakhani, K. R. (2010). Marginality and Problem-Solving Effectiveness in Broadcast Search. Organization Science, 21(5), 1-18.

Kakihara, M. (2004). Practising Mobile Professional Work: Tales of Locational, Operational, and Interactional Mobility. The Journal of Policy, Regulation and Strategy for Telecommunication, Information and Media, (6)3, 180-187.

Kapp, K. M. (2012). The Gamification of Learning and Instruction: Game-Based Methods and Strategies for Training and Education. San Francisco, CA: Pfeiffer (Wiley).

Karl, K. (2005). Attitudes toward Workplace Fun: a Three Sector Comparison. Journal of Leadership \& Organizational Studies, 12(2), 1-17.

Kleiber, D. A., Walker, G., \& Mannell, R. C. (2011). a Social Psychology of Leisure (2nd ed.). State College: Venture Publishing, Inc.

Kotro, T. (2007). User Orientation through Experience: a Study of Hobbyist Knowing in Product. Human Technology, 3(2), 154-166.

Laguna, M., \& Marklund, J. (2005). Business Process Modeling, Simulation, and Design. Upper Saddle River: Pearson Prentice Hall.

Lakhani, K. R., \& Wolf, R. G. (2003). Why Hackers Do What They Do: Understanding Motivation and Effort in Free/Open Source Software Projects. MIT Sloan Working Paper, 4425-03. https://ssrn.com/abstract $=443040$ or http://dx.doi.org/10.2139/ssrn.443040 .

Lee, J., \& Hammer, J. (2011). Gamification in Edu- 
cation: What, How, Why Bother?. Gamification in Education: What, How, Why Bother?. Academic Exchange Quarterly, 15(2), 1-5.

Madjar, N., Oldham, G. R., \& Pratt, M. G. (2002). There's no Place Like Home?. the Contributions of Work and Nonwork Creativity Support to Employees Creative Performance. Academy of Management Journal, 45(4), 757768.

Manoux, S. A., Richards, M., \& Marmot, M. (2003). Leisure Activities and Cognitive Function in Middle Age: Journal of Epidemiology and Community Health, 57(11), 907-913.

Martins, L. L., Gilson, L. L., Maynard, M. T., \& Gilson, L. L. (2004). Journal of Management, 30(6), 805-835.

McGonigal, J. (2011). Reality is Broken: Why Games Make Us Better and How They Can Change the World. NY: The Penguin Press.

Medaille, A. (2010). The Power of Play : Fostering Creativity and Innovation in Libraries. Journal of Library Innovation, 1(October), 8-23.

Mollick, E. R., \& Rothbard, N. (2014). Mandatory Fun: Consent, Gamification and the Impact of Games at Work. The Wharton School Research Paper Series. Philadelphia, PA: University of Pennsylvania.

Muntean, C. I. (2011). Raising Engagement in ELearning through Gamification. Proceedings. The 6th International Conference on Virtual Learning ICVL 2011, (1), 323-329.

Palmer D, Lunceford S, Patton AJ (2012) The Engagement Economy: How Gamification is Reshaping Businesses. Deloitte Review, 11, 52-69.

Pigram, J. J., Jenkins, J. M. (2006). Outdoor Recreation Management. NY: Routledge.

Pine, J., \& Gilmore, J. H. (2011). The Experience Economy: Past, Present and Future. Handbook on the Experience Economy.

Pryor, M .G., Singleton, L.P., Taneja, S., \& Humphreys, J. H. (2010), Workplace Fun and its Correlates: a Conceptual Inquiry, International Journal of Management, (27)2, 294-302.

Rahi, S. (2017). Research Design and Methods: a Systematic Review of Research Paradigms, Sampling Issues and Instruments Development International Journal of Economics. International Journal of Economics \& Management Sciences, 6(2), 1-5.

Ravenscroft, N., Gilchrist, P., Ravenscroft, N., \& Gilchrist, P. (2009). The Emergent Working
Society of Leisure. Journal of Leisure Research, 41(1), 22-39.

Santrock, J. W. (2008). A Topical Approach to Lifespan Development. NY: McGraw-Hill Companies, Inc.

Serrat, O. (2009). Harnessing Creativity and Innovation in the. Asian Development Bank, 61(September), 1-11.

Siha, S. M., \& Monroe, R. W. (2006). Telecommuting's Past and Future: Telecommuting's. A Literature Review and Research Agenda, 12(4), 455-482.

Spreitzer, G. M., Cameron, L., \& Garrett, L. (2017). Alternative Work Arrangements: Two Images of the New World of Work. Annual Review of Organizational Psychology and Organizational Behavior, 4(1), 473-499.

Teodoro, R., Ozturk, P., Naaman, M., Mason, W., Lindqvist, J., Tech, C., \& York, N. (2014). The Motivations and Experiences of the On-Demand Mobile Workforce. Performing Crowd Work, 236-247.

Tews, M. J., Michel, J. W., \& Bartlett, A. (2012). The Fundamental Role of Workplace Fun in Applicant Attraction. Journal of Leadership \& Organizational Studies, 19(1), 105-114.

Torrance, E. P., Ph, D., Torrance, E. P., Fitzgerald, K., \& Batson, A. (2000). The Rationale and Validation of the Torrance Tests of Creative Thinking, Verbal and Figural. Tempo, 20(2), 1-35.

Tremblay, D. (2002). Balancing Work and Family with Telework? Organizational Issues and Challenges for Women and Managers. Women in Management Review, 17(3/4), 157-170.

Uglanova, E., \& Dettmers, J. (2018). Sustained Effects of Flexible Working Time Arrangements on Subjective Well-Being. Journal of Happiness Studies, 19(6), 1727-1748.

Watson, I., \& Lightfoot, D. J. (2003). Mobile working with Connexions. Facilities, 21(13), 347352.

West, M.A. (2004). Effective Teamwork: Practical Lessons from Organizational Research. Oxford: Blackwell Publishing.

Zichermann, G., \& Cunningham, C. (2011). Gamification by Design: Implementing Game Mechanics in Web and Mobile Apps. Cambridge, MA: O'Reilly Media

Zimmerer, T., \& Scarborough, N. (2008). Essentials of Entrepreneurship and Small Business Management. NJ: Prentice-Hall. 